\title{
The Strategy of Religious Nationalist Content of the Gerindra Party in Improving the Political Participation of Millennials (Case Study of @Gerindra Instagram Account and Gerindra Twitter Account)
}

\author{
Andicha Vebiyatama ${ }^{1}$, Henni Gusfa ${ }^{2}$ \\ \{andika.vebiyatama@gmail.com ${ }^{1}$, henni.gusfa@mercubuana.ac.id ${ }^{2}$ \} \\ Universitas Mercu Buana, Indonesia ${ }^{1,2}$
}

\begin{abstract}
As technology develops, variations in content creation are generated with the creation of interactions on the virtual. This situation is an opportunity for political parties to achieve the target of getting voter sympathy, especially the values of the Gerindra party in internalizing religious nationalist values. The purpose of this study is to analyze the management of social media content by the Gerindra Party in instilling the values of the Religious Nationalists in increasing the political participation of millennial generations. New media becomes interactive media in political marketing strategies that are strengthened by the concept of content strategy tools that can increase the political participation of millennials in social media. This study uses a constructivism paradigm with a case study approach. The research informant was the Gerindra Party social media team. Primary data obtained from social media observations and interviews. The results of this study are religious nationalist content managed with the situation ahead of the campaign with content strategy tools including conducting content audits, determining user persona, setting content vision statements, choosing channel strategy. The approach taken turns out to provide more interesting creativity when content co-creation is carried out with responses that are accommodated by the media team by accepting ideas and input from comments on the content presented.
\end{abstract}

Keywords: Social Media, Strategy Tools, Participation, Millennials.

\section{Introduction}

Matching the vision and communicating it belongs to the Joint is a strategy by internalizing the values substituted in political messages and actions of political actors, according to Althoff [1] orientation of political communication is a battle of interests to influence, seize, defend, and expand power exercised by political communicators, namely the elite (ruler) and the public (controlled). The phenomenon of political communication in the presidential and vicepresidential elections becomes a stage that expresses freedom, and the dynamics of communication including political campaigns, imaging and use of social media.

Through the election system, it became a historical moment for the Indonesian people, where the candidates for regional head were elected directly. Of course, the big role given to the people especially millennial generation to determine their respective regional heads, according to Hidayat [2] revealed the data of the General Election Commission (KPU), the number of millennial voters reached 70 million - 80 million people from 193 million voters. That is, about 
35-40 percent have a big influence on the election results and determine who the leaders of the future. Of course, this percentage of the millennial generation turnout becomes an opportunity to contribute votes in the 2019 Election. The potential of millennial generation is an easy target for politicians who want to put themselves forward as councilors, president and vice president and a strategy is needed to get alignments from millennials and one a tool that is easy, inexpensive and becomes a millennial life style is the use of technology. Social media is increasingly popular in its development both as a platform for sharing news and as an ecology of communication, According to de Vreese [3] reveals that social media provides direct access to the public without journalistic interference, offering the possibility to establish close and direct relationships with the community, fostering the potential to personalize forms of communication, and can create a feeling of belonging to the community, and recognition among other groups that are spread. Thus, significantly expanding the reach of their messages and extending the duration and impact of messages in the ongoing news cycle.

Political messages are inseparable from the context of nationalist insight, this is what has become the vision of a virtual message by the Gerindra party, which has been internalized as nationalism and religion which tends to weaken among millennial groups. This is reinforced by Amin [4] that nationalism or nationalism is one of them caused by an understanding of religious values that tend to be formalistic, narrow, shallow, and exclusive. The issue of religion becomes one of the strategic instruments in the election contestation in Indonesia [5]. Religious issues are often produced without facts based solely on political interests in gaining votes in regional elections, legislative elections, and presidential elections. The relationship between religion and politics becomes problematic when it relates to the particularity of local politics, for example the emergence of identity issues, such as religious sentiments, ethnicity, native sons and majority-minorities.

Gerindra Party entered as a participant in the 2019 Election and became one of the parties participating in the Indonesian coalition Adil Makmur which carries the pair of Candidates for President-Vice-President Prabowo Subianto-Sandiaga Salahuddin Uno. Recognizing the important role of social media as a way to win in elections is the right step. Social media is an online media. Its users can easily participate, share and create content including blogs, social networks, wikis, forums and the virtual world [6]. Where someone can create a personal web page to share information and communicate with everyone who joins the same social media. Social media makes it easy for us to communicate, give each other feedback openly on information that is shared quickly and real-time. Social media has become one of the most important institutions in the course of political campaigns. The reason is simple, namely in an era where universal suffrage is carried out, the scope that political parties must reach is very broad. Therefore, there is a need for a message intermediary who is able to reach the masses of voters in the state center.

Millennial generation is a concern in this study because millennial generation has an attitude that wants to be independent to make their own choices. Millennial generation in this case is the first voter to use his voting rights. According to Widodo [7] survey at the end of last November (2018) that, millennial generation or novice voters have not yet made many choices in seeing politics today, they do not have much information and reasons for choosing a candidate pair.

This concerns the author to analyze social media managed by Gerindra, because according to Jemadu [8] among other political parties the Gerindra party is the youngest party to use social media accounts, then the age of the party's Facebook account and the number of likes has a correlation score that is weaker (0.44) compared to the age of Instagram / I_A accounts and Instagram followers $(0.76)$ or on YouTube $(0.7)$ and Twitter $(0.67)$ because the popularity 
patterns of using social media on the internet are different in each party . Indonesian Democratic Party of Struggle (PDI-P) is the party with the oldest Facebook account. Join this social networking site since 2008, two years since Facebook is open to anyone over 13 years who has an email address. Meanwhile, the National Mandate Party (PAN) has joined Facebook for the past 8 years, followed by the Prosperous Justice Party (PKS) whose account has been registered in the last 7 years ago.

However, it is interesting to note that despite being the first three Indonesian political parties to create a Facebook account, the popularity of PDI-P (around 1.5 million followers), PAN $(187,000)$, and PKS $(615,000)$ on Facebook is far lower than Gerindra with around 3.6 million followers and the Indonesian Solidarity Party with around 2.9 million followers. the age of the party does not determine the popularity of the party in cyberspace. Gerindra which was founded only 10 years ago has become the most popular party on all social media, except YouTube. Strengthened by the results of research Putra [9] the use of new media as a means of campaigning in the 2018 West Java Governor Election shows that campaigns using social media are seen as more effective than conventional media. This is because people trust more the words of friends or colleagues they know on social media.

Social media is in the top five in Indonesia occupied by Facebook, Instagram, Twitter, Snapchat, and LinkedIn. Indonesia itself occupies the third rank as a country with users as well as the largest target audience of Facebook ads in the world, with a total of 130 million monthly active users. 56 percent of Facebook users were detected as male users while 44 percent were female. While Instagram has 62 million monthly active users in Indonesia with a 51 percent percentage of male users, ahead of female users with 49 percent penetration. Twitter has 6.43 million active monthly users in Indonesia, male Twitter users dominate this platform with a percentage of 65 percent, while female users only 35 percent. Snapchat, although the reverberations are rarely heard in Indonesia, secretly has 3.8 million monthly active users. The majority of users are women with a percentage of 87 percent, while male users only 89 percent. LinkedIn has 12 million registered users in Indonesia with a percentage of 59 percent male internet users and 41 percent are female.

In the 2014 election, it was estimated that there were around 18.3 million beginner voters from the younger generation aged between 17 and 24 years [2]. In terms of age, it's likely that most of them are social media users. They are expected to be able to use their right to vote in elections and become the target of political parties and politicians to win their votes. Millennials are the generation born around the early 1980s until the early 2000s [10]. In 2019 millennials are voters aged 17-38 years. Millennial is also described as a generation that tends to be open minded, more tolerant of minority matters, very confident, tends to be liberal and very interested in ideas or new ways of life. In terms of politics, this generation tends to move, so that it becomes a challenge for political groups who want to approach [11]. based on the above background, the purpose of this study is to analyze the national and religious Gerindra content strategy tools in increasing millennial participation.

\section{Literature Review}

\subsection{Strategy}

Strategy according to Firmansyah [12] is a careful plan regarding activities to achieve specific goals and are interconnected in terms of time and size. So, the strategy here is the art 
and science of using and developing forces (whether ideological, political, social, cultural or legal) to achieve predetermined goals. Therefore, strategy is also a secret that must be hidden by communication planners, especially in conducting political campaigns and social marketing [13].

\subsection{Political and Media Communication}

Another element that is no less important in political communication is the media or communication channel used in this case the media used is social media. According to Utari [14] Social Media is an online media where users can easily participate. Participating in the sense that someone will easily share information, create content or content to be conveyed to others, make comments on the input they receive and so on. The internet as a medium of communication and information exchange, has the opportunity to revolutionize the democratic system, structure and process that we have been familiar with Firmansyah [12]. All can be done quickly and unlimitedly.

\subsection{Political Messages}

Political communication requires attractive packaging to market, in polytechnic communication, the strategy of packing political messages is very important. Packaging plays a role in directing the way the public understands the message being conveyed. The message raised must be in line with the current political issues in the community and then refined in the form of social media content. In addition, the polytechnic message should also be able to explain the issues that are currently being faced by the public. Furthermore, the political message is not just a discourse, but it contains a way of solving problems [12].

\subsection{Content Strategy Tools}

According to Lovinger [15] explains content strategies using words and data to create clear content that supports experiences in an interactive and meaningful form. Before starting to make koten, it's good to see some of the tools that exist in the content strategy tools. The first step is Content Audit. As stated Blakiston [16] By understanding what content exists, organizations can plan better how to manage what already exists and also plan for the future. Content audits can be quantitative, qualitative, or mixed, and generally use online information search (such as websites, online media, and social media) in searching for topics or issues to be discussed.

After the Gerindra Party social media team has a good understanding of what content will be made through content audits. Begin the second step, User Persona, the user persona is a representation of the user. Personas users learn more about social media visitors or social media political participants about their goals, and the need for information. Persona enables the Gerindra Party social media team to make content-making decisions based on user needs, not opinion.

The third step is Content Vision Statement. This is where the team determines the purpose of creating and using social media content. Gerindra party social media teams must use persona while developing statements about the purpose of their content which will be distributed to social media. Content vision statements must be linked to party institutional goals. In other words, content will help the party achieve its goals. The content vision statement will then flow to all content decisions posted on social media. The more people on the social media team who can work together in building a statement of content goals, the better the final outcome. 
The fourth step is Channel Strategy. The channel strategy is the process of planning on what channel (in this case, usually a social media platform) the Gerindra party will use. The channel strategy is very important to ensure the right time and place to post, and consider what type of content is best for reaching users and creating engagement. For example, Instagram was designed as a place for interesting photography, but recently greater involvement was achieved with short quotes and videos. Twitter was designed as a place for discussion, very identical to textual content. The social media team also needs to decide which channel sound to apply.

The process of making messages in the form of social media content is not immune to the values conveyed including nationalism and religious values. The embodiment of the attitude of nationalism includes love behavior towards the motherland, upholding unity and unity, and having an attitude of self-sacrifice [17]. Embodiments of religious attitudes, including faith and piety, patience, sincerity, and always grateful [18].

\subsection{Political Participation}

According to Keith Faus Political participation is the active involvement of individuals or groups in the government process. Damsar [19] thus individuals here are very active role in implementing government activities. Millennial generation known as Generation $\mathrm{Y}$ is a generation that is now becoming a lot of attention in various fields. This generation was born after generation $\mathrm{X}$ in the range of 1981 to 2000 [20][21]. Based on some of the above theories, it can be defined that political participation is active community involvement in politics that is done voluntarily in social media, which can be realized by giving comments, follower candidates, giving opinions, and followers of political parties [22].

\section{Research Methodology}

This research uses the constructivism paradigm. The constructivist paradigm is a paradigm aimed at discovering how the event or reality is constructed, and in what way the construction is formed [23]. This study uses a qualitative approach that examines the strategy of religious nationalist content through social media using the case study method. Case study is a systematic research that investigates phenomena in real life contexts, where the boundaries between phenomena and contexts do not appear explicitly, and where multiple sources of evidence are utilized [24].

The type of data in this study are in-depth interviews (dept interviews) and standardized interviews (standardized interview). Determination of the sources of this research is based on the research method of taking sources with consideration of informants who know and are relevant to the issues that the author wants to know [25]. In this case the speaker is the TOGPS team (Gerindra Prabowo Online Team Subianto).

\section{Results and Discussion}

\subsection{Gerindra Party Profile}

History of the founding of the Gerindra Party Starting from concern, the Gerindra Party was born to lift the people from the snares of poverty, due to the play of people who do not care 
about welfare. The idea of establishing a party was started in the circle of Hashim and Prabowo people. However, not all agree. There are also those who refuse, with the excuse that if they want to get involved in the political process, they should just join the existing political parties. After a long and arduous debate, it was finally agreed that there needed to be a new party that truly had a manifesto of struggle for the welfare of the people. To finalize the party concept, in December 2007, at a house, which became the headquarters of IPS (Institute for Policy Studies) in Bendungan Hilir, a number of names were gathered. Besides Fadli Zon, there were also Ahmad Muzani, M. Asrian Mirza, Amran Nasution, Halida Hatta, Tanya Alwi, Haris Bobihoe, Sufmi Dasco Ahmad, Muchdi Pr, Widjono Hardjanto and Prof. Suhardi. They discussed the statutes and bylaws of the party that will be formed. The formation of the Gerindra Party is quite urgent. Because it was declared close to the time of registration and the election campaign period, which was on February 6, 2008. In that declaration, the party's vision, mission and manifesto of the party's struggle were realized, namely the realization of an independent, sovereign, united, democratic, fair, prosperous and civilized society. and belief based on Pancasila as stipulated in the opening of the 1945 Constitution of the Republic of Indonesia.

\subsection{Social Media Content Strategy}

Today Media and Politics, it seems to be difficult to separate. Advances in technology in the era of globalization will bring major changes, especially the emergence of social networks, such as Facebook, Twitter and portals, so that the public will also use their interests, among others, for political campaign strategies. Social media used as a political marketing communication strategy is one of the right ways in which the Gerindra party utilizes social media such as Instagram and Twitter that can be accessed by political participants on social media.

In conducting political campaigns through social media, strategies are needed in creating content, content auditing is highly recommended for the initial steps of creating social media content, where research in the campaign is very necessary given the importance of the information to be conveyed, so that the social media team of the Gerindra party can determine the theme or certain issues that are needed in social media campaigns to be more precise.

"In order to process every campaign content, we will first conduct a research" (TOGPS, 25 July 2019).

In this case, the Gerindra party social media team is trying to find out things that are increasingly being discussed or favored by the public, especially millennials. For example, campaign content on social media is delivered in a language that is easily understood by millennials and related to millennial social development. In addition, the Gerindra party social media team also conducted research on the condition of the nation's condition in relation to nationalism and religion which were considered very important among young people. So, through social media, the Gerindra Party is trying to embrace its followers.

The next step is User Persona, the user's persona is a representation of the user. Personas users learn more about social media visitors or social media political participants about their goals, and the need for information. With the aim of knowing the desires of the target or the intended target or social probabilities, what is happening and needs to be fixed.

"Yes, we have a designer team, there is a research team, there is a editing team like that, videographers exist." (TOGPS, July 25, 2019). 
In the process of producing social media content the Gerindra Party places more emphasis on how to communicate a message to participants or followers to form a positive image in the eyes of political participants on social media. Here the Gerindra party social media team is demanded to be observant in choosing the wishes of the participants. The published content is adjusted to the needs of the participants, which can be seen from the trending topic of social media and Google Trend.

The third step is Content Vision Statement. This is where the team determines the purpose of creating and using social media content. Gerindra party social media teams must use persona while developing statements about the purpose of their content which will be distributed to social media. In the campaign process, issues packaged in the form of content will be published in advance, with the aim of the Gerindra party to utilize social media, among others, to increase political participation, especially the younger generation or millennial generation.

"Actually, that's also the main point. One of our goals is to use social media as well to increase the main political participation for the younger generation, too". (TOGPS, July 25, 2019).

Content vision statements must be linked to party institutional goals. In other words, content will help the party achieve its goals. The content vision statement will then flow to all content decisions posted on social media. The more people on the social media team who can work together in building a statement of content goals, the better the final outcome.

"Gerindra is trying to optimize the use of social media because primarily we do not have affiliations or have relations with certain mainstream media like that". (TOGPS, July 25, 2019).

The role of social media is quite supportive of the Gerindra Party campaign process, because the Gerindra Party is not affiliated with the mainstream media.

"To reach the widest range of mainstream media, we can at least reach out with social media and that is clearly very beneficial for Gerindra". (TOGPS, July 25, 2019).

Social media can help convey party ideas or ideas in the form of content. Which the message distribution process requires a short and fast and can reach a broad target.

The final step in the content strategy is the Channel Strategy. The channel strategy is the planning process on what channel (in this case, usually a social media platform) the gerindra party will use.

"If the average social media is all mainstream social media, the main thing we have is that almost everyone uses Facebook, especially because our followers are the most on Facebook, Twitter, Instagram, and YouTube." (TOGPS, July 25, 2019).

A media channel selection strategy is very important to ensure the right time and place to post, and consider what type of content is most appropriate for reaching users and creating engagement. For example, Instagram was designed as a place for interesting photography, but recently greater involvement was achieved with short quotes and videos. Twitter was designed 
as a place for discussion, very identical to textual content. The social media team also needs to decide which channel sound to apply.

\subsection{Millennial Generation Political Participation in Social Media}

Social media and millennial generation are inseparable parts now. Where users can easily participate, share and create content including blogs, social networks, wikis, forums and the virtual world. Social media is also an online media that supports social interaction and social media using web-based technology that turns communication into interactive dialogue.

Submitting campaign messages in the form of content using social media as a channel is very appropriate to the intended target of prospective voter voters and active political participants on the social media.

"Therefore, we understand the characteristics of our young generation in general who still do not really care about politics. So, we open the discussion so that they are interested to see, so that they can imagine later those who lead this country, going forward, this is a problem that we are faced with this", (TOGPS, July 25, 2019).

Where political participants on social media take advantage of the features provided by the medium in the form of following party accounts, like content that is posted and even responds to comments and shares.

"The Gerindra party puts itself on equal footing with its followers, especially on social media, so we call our friends followers 'friends', so on social media we are not to patronize, but open up discussion space related to campaign content", (TOGPS, July $25,2019)$.

Campaigns through social media do not always run smoothly, because the communication is part of public communication or sometimes called heterogeneous mass communication. In addition, in social media there are certainly many interesting treats from various accounts, so the competition in creating content is very tight. Content that is not interesting will be easily abandoned or even not glance at all by social media visitors. Therefore, it requires high creativity to create content, especially campaign content to be able to attract the support of social media audiences.

\subsection{Discussion}

Social media is the use of web and mobile-based technology to create and share information beyond geographical, social, political or demographic boundaries through participatory and collaborative community interaction. Millennial generation is known as the generation that accesses the internet the most in their daily lives.

Using Twitter as a campaign medium, Twitter is a service for friends, family, and coworkers or businesses to communicate and stay connected through fast and frequent message exchanges. Users post a Tweet, which can contain photos, videos, links and text. This message is posted to your profile, sent to followers, and can be searched on Twitter search [26].

Gerindra's Twitter party, @gerindra, has 522.5 thousand Followers accounts and follows 3,963 accounts, counted since it first registered a Twitter account in October 2011 [27]. 
Instagram is a photo and video sharing application that allows users to take photos, take videos, apply digital filters, and other networking activities [28].

Gerindra's Instagram party, @gerindra, has 542 thousand followers accounts and has participated in 383 accounts, starting from the first time registering an Instagram account on July 24, 2013 [29].

The content strategy in a campaign activity really requires a mature design process so that the goals are right on target. Various campaign strategies can be done through various intermediaries, in this case it can be done through social media. The choice of social media as a campaign media is because most of the election participants are millennials who generally tend to actively use social media.

Social media is considered very appropriate in helping the campaign process. Through social media political parties can reach large areas to campaign for a variety of ideas and vision and mission in order to gain popular support. Because social media is a medium that facilitates collaboration between users that produce content (user generated content), as explained by Mandiberg in Nasrullah [30]. And to create a creative content as one of the campaign activities is not easy, research is needed so that the data presented is accurate.

Researchers also made observations on social media content that had been published by the Gerindrs Party, which until now is still airing on social media accounts. Where the Gerindra Party tries to show a nationalist and religious attitude, this can be seen from its posts on social media accounts.

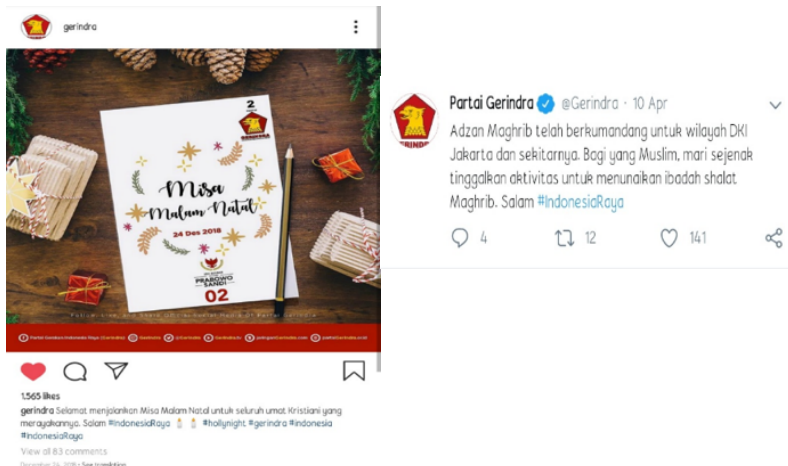

Fig. 1. Gerindra Party Social Media Content (twitter.com/gerindra and instagram.com/gerindra).

The religious-themed content above shows that prioritizing worship is far more important than other activities. Then Giving congratulations to non-Muslims, is also a positive action, in order to achieve an attitude of tolerance among fellow religious communities because our pluralistic Indonesia consists of diverse cultures, including religion. 


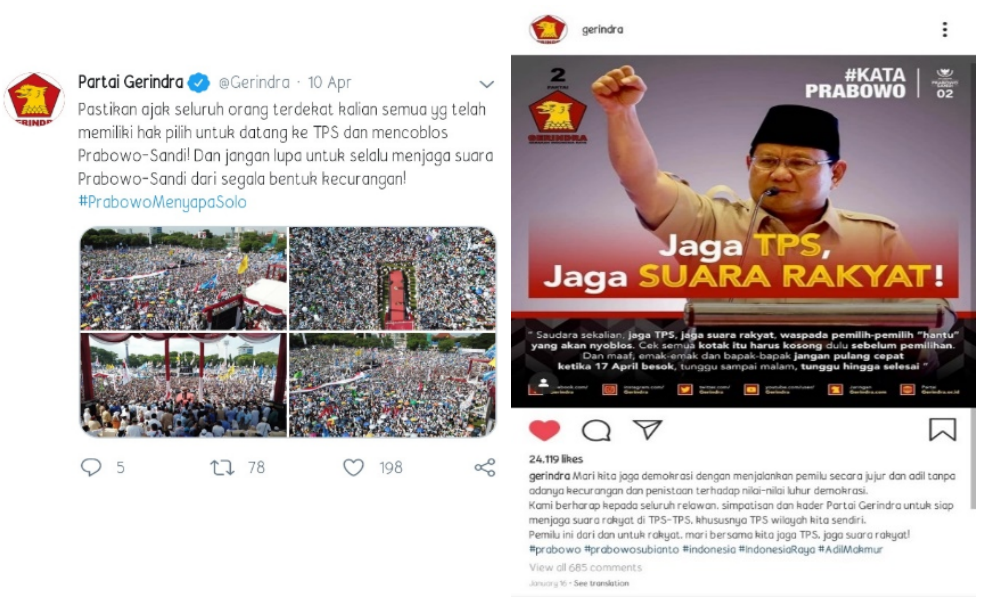

Fig. 2. Gerindra Party Social Media Content (twitter.com/gerindra and instagram.com/gerindra).

As in the picture above, on the Gerindra party's Instagram account that says "Keep the polling station, keep the people's voice!", Short sentences that are sufficient to motivate social media visitors who might be able to arouse nationalism in social media audiences. Because by keeping the polling stations, it means that they take part in the implementation of fair and fair elections. The posting on the Gerindra party's Twitter account illustrated the invitation to exercise their voting rights by coming to the polling station and keeping the votes chosen from fraud.

In the social media space only information that is valuable facts. To achieve the belief that information is factual, debates often arise. Social media has only a significant effect on politicians who work around the clock. Not an instant job once every five years. Those who intensely spread ideas and discuss in a particular field in depth all the time will get results during the election.

"We are consistent in maintaining the quality of the quantity of content". (TOGPS, July 25, 2019).

The nature of campaigns on social media can be the opposite of campaigns in the real world. If in the real world the campaign is so noisy, loud but without real evidence, on social media is the antithesis of the noise and noise, which is meaningful. Every written word has meaning, has its own proof and needs to be maintained for the quality of each published content.

"For our campaign, there are those who jump directly into the community, but that's the scope, for example, we have a traveling list to one of the villages, the most outreach is two or three villages around, do you know who heard or participated, but if for example we preach that activity on social media, then the reach becomes even wider". (TOGPS, July 25, 2019).

The campaign is said to be successful if it combines online and offline methods. What is meant by an offline campaign is a direct campaign to meet with the community, where the role of social media here is very useful as a means of disseminating information that cannot be 
reached if the campaign is carried out directly. Social media in this case can be integrated into the overall campaign planning strategy. Campaigns that only focus on social media and the Internet may not be appropriate. Likewise, campaigns that ignore social media and are reluctant to build a social media presence will also be left behind.

The use of social media is not just a means to strengthen communication but has discussed political issues, government policies, the behavior of public figures. Social media has become a part in every life of the community including the political sphere that can be used for means of communication, self-promotion, socialization, including the promotion of political parties to build the party's image. The use of social media for politics will usually be seen when there will be elections for political campaigns.

Social media has a very important role in the campaign process, as explained above. The results show that social media plays an active role in shaping or creating a pattern that is able to influence the community in providing support for the Gerindra Party in the last election. Although we know the results may be less satisfying, still social media has helped the campaign process. Because without a social media campaign directly to the field is considered incomplete, as revealed by the Gerindra party social media team in the research results.

Content strategy tools are very focused on winning share of mind from the participation of generation of political millennials, in political marketing orientation using social media is on messages that contain nationalist and religious values as a strategy to generate reinforcement to political parties with Indonesian identity.

Gerindra party social media team chose social media as a strategic channel in the campaign process. In the channel strategy in addition to choosing the right media, the findings can be seen that channel selection alone is not enough to streamline the message, but a campaign strategy in social media that is compiled should be able to see when the right time and the right message is disseminated to the public. As with television media that have a special time or prime time. So when posting content on social media, you also need to look at the right period or time so that the contents of the campaign content can be adjusted. Thus, the message delivered will be right on target. Agder with Synder in Gudykunts [31] which explains that communication campaigns are organized communication actions directed at specific audiences, at certain time periods in order to achieve certain goals.

"Basically we follow every day it follows the Prime Time hours" people play social media "it is usually in the same morning in the afternoon before that night but for example it depends on it if it depends on each platform, usually on each platform it's different but usually in the morning and evening". (TOGPS, July 25, 2019).

This time period needs to be considered before posting campaign content on social media. So, in compiling the content strategy there are 6 things to consider, content audit, user persona, content vision statement, channel strategy, timing post and engagement of Strength. Timing post is a time period strategy for posting where the content to be published is arranged or adjusted at certain times or certain moments. For example, the campaign delivered by the Gerindra party on Christmas Day. When giving a Merry Christmas greeting it can be considered as a campaign strategy which shows a party that upholds the values of solidarity. In addition, the timing post can be interpreted as a time adjustment strategy, where the publication of content is done at certain hours (prime time). For example, following the prime-time hours "people play social media" which is usually done in the morning, afternoon or late evening. These hours are very important to be known by the social media admin, so that the published messages can be read by his followers. 
Engagement of Strength is a strategy undertaken by the Gerindra party social media team to always respond to any feedback entered in their social media accounts. Not only that, the Gerindra party social media team also invited political participants to discuss the issue being discussed. Building engagements with political participants is considered very appropriate in strengthening support for the party.

"We do not intend to patronize any content we produce that we publish is not to patronize, but rather to invite this discussion, there are these issues, according to you, like what we can do with the position of the Gerindra party, what we can do now, right? something like that". (TOGPS, July 25, 2019).

Then, in social media active account management is needed, so that feedback is not delayed, thus the fabric of communication in this public space is lively. The management of this active social media account will help the party's campaign process, especially the Gerindra party in conducting evaluations, as well as knowing the public's wishes, thus the main purpose of the Gerindra party in conveying political messages related to the values of nationalism-religious can be accepted and understood the meaning of the message to be conveyed.

Strengthening religious nationalist messages on messages packaged in the form of content on social media that is made referring to content strategy tools with the aim of being a database of political parties that will be used as assets of candidates who are loyal to the party both as opposition and coalition in several the next year, which strengthens the figure of the party, which will lead the millennial generation to strengthen the personality value of the Gerindra party as the party that gives birth to future leaders.

\section{Conclusions}

The content strategy tool implemented in winning the popularity of the Gerindra party in the message of nationalism and religion is a message that uploads changes for a more just and prosperous life for future generations, this is conveyed in social media as a political vision. Internalization of nationalist and religious messages is raised by diversity and unity, the use of social media is carried out by the process of applying the content of strategy to create a spirit of struggle, diversity and a sense of belonging to the nation, love of the motherland. Participation that is bound in nationalism and religious messages is a message that binds millennial emotions in the sense of shared ownership of the homeland and its resources, for this commentary and repost conducted by millennials is configured as a strategy for making messages together in the same space and time, so it concludes the content strategy applied in the nationalist and religious message of the Gerindra party, the next stage was the timing of the post and engagement of Strength. Millennial participation in social media results from the management of nationalist and religious messages created by managers of social media and repost and posting Gerindra millennial voters.

\section{References}

[1] P. Althoff and M. Rush, "Pengantar Sosiologi Politik," Jakarta PT Raja Graf. Persada, 2005.

[2] A. N. Hidayat, "Beda Cara Generasi Milenial dalam Politik," Kompas, 2019.

[3] C. H. De Vreese, F. Esser, T. Aalberg, C. Reinemann, and J. Stanyer, "Populism as an expression of political communication content and style: A new perspective," Int. J. Press., vol. 23, no. 4, 
pp. 423-438, 2018.

[4] N. Amin, "Menyemai Nasionalisme dari Spirit Agama: Upaya Meredam Radikalisme Beragama," J. Theol., vol. 23, no. 1, pp. 109-123, 2017.

[5] F. S. Ramadlan and R. Masykuri, "Marketing Isu Agama Dalam Pemilihan Kepala Daerah Di Indonesia 2015-2018," J. Penelit. Polit., vol. 15, no. 2, pp. 249-265, 2018.

[6] M. Budiyono, "Media Sosial dan Komunikasi Politik: Media Sosial sebagai Komunikasi Politik Menjelang PILKADA DKI JAKARTA 2017," J. Komun., vol. 11, no. 1, pp. 47-62, 2016.

[7] S. Widodo, "www.news.unair.ac.id," 2019.

[8] L. Jemadu, "Jelang Pemilu 2019: Partai Mana Paling Top di Media Sosial," Suara.com, 2019.

[9] A. M. Putra, Penggunaan New Media Sebagai Sarana Kampanye Politik Pada Konsistensi Pilkada Jabar 2018. Jakarta: Universitas Mercu Buana, 2017.

[10] Badan Pusat Statistik dan Kementerian Pemberdayaan Perempuan dan Perlindungan Anak, Statistik Gender Tematik: Profil Generasi Milenial Indonesia. Jakarta: Badan Pusat Statistik dan Kementerian Pemberdayaan Perempuan dan Perlindungan Anak, 2018.

[11] Kaili Post, "Pendapat Berebut Milenia," Kaili Post.

[12] P. Firmansyah, "Marketing Politik: Antara Pemahaman dan Realitas." Jakarta: Yayasan Obor, 2008.

[13] H. Cangara, "Perencanaan dan strategi komunikasi," Jakarta Raja Graf. Persada, 2013.

[14] P. Utari, "Media Sosial, New Media dan Gender dalam Pusaran Teori Komunikasi," Bab Buku Komun., vol. 2, 2011.

[15] R. Lovinger, "Content strategy: The philosophy of data," Boxesandarrows, 2007.

[16] R. Blakiston, "Developing a content strategy for an academic library website," J. Electron. Resour. Librariansh., vol. 25, no. 3, pp. 175-191, 2013.

[17] K. Budiyono, Nilai-nilai kepribadian dan kejuangan bangsa Indonesia. Alfabeta, 2007.

[18] A. Majid, A. S. Wardan, and D. Andayani, Pendidikan karakter perspektif Islam. PT Remaja Rosdakarya, 2011.

[19] S. Damsar, "Pengantar Sosiologi Politik," Jakarta: Kencana Prenada, 2010.

[20] S. J. Young, J. R. Sturts, C. M. Ross, and K. T. Kim, "Generational differences and job satisfaction in leisure services," Manag. Leis., vol. 18, no. 2, pp. 152-170, 2013.

[21] S. Marwah, "Reading Women Participations on Populism Politics," Polit. Indones. Indones. Polit. Sci. Rev., vol. 4, no. 2, pp. 255-273, 2019.

[22] A. J. Tri, "Dinamika Partisipasi Politik Remaja Melalui Media Sosial," J. Visi Komun., vol. 13, no. 02, pp. 281-295, 2014.

[23] L. J. Moleong, Metodologi Penelitian Kualitatif. Bandung: PT. Remaja Rosdakarya, 2010.

[24] R. K. Yin, "Studi kasus: desain dan metode," Jakarta PT. Raja Graf. Perkasa, 2002.

[25] Sugiyono, Memahami Penelitian Kualitatif. 2005.

[26] Twitter, "Help Desk," Twitter, 2019.

[27] Gerindra, "Post," www.twitter.com/gerindra, 2019.

[28] A. A. Sendari, "Instagram adalah Platform Berbagi Foto dan Video: Ini Deretan Fitur Canggihnya," Liputan 6, 2019.

[29] Gerindra, "Post," www.instagram.com/gerindra, 2019.

[30] R. Nasrullah, "Peer Riview Etnografi Virtual Riset Komunikasi Budaya Sosioteknologi Di Internet (Reviewer 1)." Simbiosa Rekatama Media, 2017.

[31] M. Bella and W. B. G. B. Mody, Handbook of international and intercultural communication. Sage, 2002. 